\title{
Radioiodine-resistant metastases of well-differentiated thyroid cancer, analysis of tumor characteristics and primary surgical intervention
}

\author{
M. V. Ostafiichuk ${ }^{(B, C, D}$, A. Ye. Kovalenko ${ }^{A, D, F}, Y u$. M. Tarashchenko ${ }^{E}$ \\ SI "V. P. Komisarenko Institute of Endocrinology and Metabolism of the National Academy of Medical Sciences of Ukraine”, Kyiv
}

A - research concept and design; B - collection and/or assembly of data; C - data analysis and interpretation; D - writing the article;

$\mathrm{E}$ - critical revision of the article; $\mathrm{F}$ - final approval of the article

Key words: thyroid cancer, surgical treatment, radioiodine-resistant metastases, radioiodine therapy.

Zaporozhye medical journal 2021; 23 (5), 670-676

*E-mail: maryanostafiychuk@ gmail.com
The aim of this article is to assess the initial status, characteristics of the tumor process and initial surgical treatment in patients with well-differentiated thyroid carcinomas who subsequently showed resistance to ${ }^{131}$ I therapy, comparing with the control group of patients who achieved a positive effect of ${ }^{131}$ I therapy.

Materials and methods. In total, 156 cases of well-differentiated thyroid cancer were analyzed. The control group consisted of 189 patients who showed complete responses to treatment of metastases after ${ }^{131} \mathrm{I}$ therapy and the confirmed relapse-free period. The patients were operated and followed up in the Department of Endocrine Gland Surgery of SI "V. P. Komisarenko Institute of Endocrinology and Metabolism of the National Academy of Medical Sciences of Ukraine" between 1990 and 2019.

Results. Based on our study, in the group of radioiodine-resistant metastases, there was a 3.1:1.0 predominance of women over men; whereas in the control group, this ratio was 1.4:1.0. It was noted that resistance to radioactive iodine in patients under 20 years of age was 4 times significantly lower (10.26\%) comparing with the radiosensitive group (41.90\%). In the age group of 41-60 years, radioiodine resistance was 6.5 times higher than that in the comparison group (39.10\% and $6.35 \%)$, and in the age group over 61 years -11 times (11.54\% and $1.05 \%)$. The impact analysis of radiation exposure on the radioiodine refractoriness occurrence revealed that among patients living in radiation-contaminated areas of Ukraine in 1986 following the Chornobyl accident, there were no significant differences in the development of resistance to radioactive iodine (resistance to ${ }^{131}$ I $-51.92 \%$ $(n=81)$, treatment response $\left.{ }^{131} \mid-64.02 \%(n=121)\right)$. These differences may be due to the younger age of patients affected by radiation and better sensitivity to radioiodine compared to the main group patients. The maximum number of radioiodine-resistant observations was in the intermediate risk group $(71.15 \% ; n=111)$. Worth noting is the significant number of radioiodine-resistant metastases in the group where their absence was initially diagnosed $(11.53 \% ; n=18)$ and in the group where the proper assessment of lymph collectors was not performed $(29.49 \% ; n=46)$. Radioiodine resistance was significantly more common (33.97\%; $n=53$ ) in observations where the prophylactic central dissection was not performed.

Conclusions. The main risk factors in the development of radioiodine-resistant metastases were the age of patients older than 40 years, the limited primary surgery on regional lymphatic collectors of the neck, tumor aggressiveness. Careful pre- and intraoperative assessment of regional collectors of the lymph outflow, preventive central neck dissection and extensive therapeutic dissections can reduce the risk of residual and radioiodine-resistant metastases. Timely diagnosis of metastases can improve the results of primary surgical treatment for patients with differentiated thyroid carcinoma and reduce the incidence of radioiodine resistance.

Кнючові слова: карцинома щитовиАної залози, хірургічне мікування, радіойодрезистентні метастази, радіойодтерапія.

Запорізький медичний журнал. 2021. T. 23, № 5(128). C. $670-676$

\section{Радіойодрезистентні метастази високодиференційованого раку щитовидної залози, аналіз характеристик пухлин і первинного оперативного втручання}

\section{М. В. Остафійчук, А. Є. Коваленко, Ю. М. Таращенко}

Мета роботи - оцінити первинний статус, характеристики пухлинного процесу та початкового хірургічного лікування в пацієнтів із високодиференційованими карциномами щитовидної залози, які згодом мали резистентність до терапії ${ }^{131}$, порівняно з контрольною групою хворих, які мали позитивний ефект від терапії ${ }^{131}$.

Матеріали та методи. Виконали аналіз 156 спостережень високодиференційованого раку щитовидної залози, резистентних до терапії ${ }^{131}$. Контрольна група - 189 пацієнтів, у яких визначили позитивний ефект лікування метастазів після терапії ${ }^{131}$ та доведеного безрецидивного періоду. Пацієнти прооперовані та перебували під спостереженням у відділі хірургії залоз внутрішньої секреції ДУ «Інститут ендокринології та обміну речовин імені В. П. Комісаренка НАМН України» (1990-2019рр.).

Результати. У групі радіойодрезистентних метастазів переважали жінки у співвідношенні 3,1:1,0, а у групі контролю співвідношення жінок і чоловіків становило 1,4:1,0. Виявили, що резистентність до радіоактивного йоду в пацієнтів віком до 20 років була вірогідно вчетверо нижчою (10,26 \%) порівняно з радіойодчутливою групою (41,90\%). У віковій групі 41-60 років радіойодрезистентність переважала в 6,5 раза порівняно з групою порівняння (39,10\% і 6,35 \%), а старше за 61 рік - в 11 разів (11,54\% і 1,05%). Аналізуючи вплив радіаційного опромінення на виникнення радіойодрефрактерності, виявили: серед пацієнтів, які проживали в 1986 р. на радіаційно забруднених територіях України внаслідок аварії на Чорнобильській $\mathrm{AEC}$, не було вірогідних відмінностей за розвитком стійкості до радіоактивного йоду (резистентність до ${ }^{131} \mathrm{I}-51,92 \%$ ( $n=81)$; ефект лікування ${ }^{131}$ - 64,02 \% ( $\left.n=121\right)$ ). Ці відмінності можуть бути пов'язані з молодшим віком радіаційно постраждалих пацієнтів і кращою чутливістю до радіойоду порівняно з пацієнтами основної групи. Максимальна кількість радіойодрезистентних спостережень - у групі проміжного ризику $(71,15 \% ; n=111)$. Привертає увагу чимала кількість радіойодрезистентних метастазів у групі, в якій первинно їх не діагностували (11,53\%; $n=18)$, і у групі, де не виконували належне оцінювання стану лімфатичних колекторів $(29,49 \% ; n=46)$. У спостереженнях, де профрілактичну центральну дисекцію не виконували, радіойодрезистентність визначали вірогідно частіше $(33,97$ \%; $n=53)$. 
Висновки. Основні фактори розвитку радіойодрезистентних метастазів -вік пацієнтів старше за 40 років, обмежений обсяг первинного оперативного втручання на реґіонарних лімфатичних колекторах шиї, агресивність пухлини. Ретельність до- та інтраопераційного оцінювання реґіонарних колекторів лімфовідтоку, виконання профілактичної центральної дисекції шиї та широких терапевтичних дисекцій дають змогу зменшити ризик розвитку резидуальних і радіойодрезистентних метастазів. Своєчасна діагностика метастазів дає можливість поліпшити результати первинного хірургічного лікування пацієнтів із диференційованою тиреоїдною карциномою, знизити частоту розвитку радіойодрезистентності.

\section{Радиойодрезистентные метастазы высокодифференцированного рака щитовидной железы, анализ характеристик опухолей и первичного оперативного вмешательства}

\section{М. В. Остафийчук, А. Е. Коваленко, Ю. Н. Таращенко}

Цель работы - оценить первичный статус, характеристики опухолевого процесса и начального хирургического лечения у пациентов с высокодифференцированными папиллярными карциномами щитовидной железы, впоследствии проявивших резистентность к терапии ${ }^{131}$ I, по сравнению с контрольной группой больных, у которых получен положительный эффект терапии ${ }^{131}$.

Материалы и методы. Проведён анализ 156 наблюдений высокодифференцированного рака щитовидной железы, резистентных к терапии ${ }^{131}$ I. Контрольная группа - 189 пациентов, у которых отмечен положительный эффект лечения метастазов после терапии ${ }^{131}$ | и доказанного безрецидивного периода. Пациенты оперированы и находились под наблюдением в отделе хирургии желёз внутренней секреции ДУ «Институт эндокринологии и обмена веществ имени В. П. Комиссаренко НАМН Украины» (1990-2019 гг.).

Результаты. В группе радиойодрезистентных метастазов преобладали женщины в соотношении 3,1:1,0, а в группе контроля соотношение женщин и мужчин составило 1,4:1,0. Отмечено, что резистентность к радиоактивному йоду у пациентов в возрасте до 20 лет была достоверно в 4 раза ниже (10,26 \%) по сравнению с группой эффективного лечения метастазов (41,90\%). В возрастной группе 41-60 лет радиойодрезистентность преобладала в 6,5 раза по сравнению с группой сравнения (39,10 \% и 6,35 \%), а в возрасте более 65 лет - в 11 раз (11,54 \% и 1,05\%).

При анализе влияния радиационного облучения на возникновение радиойодрефрактерности отмечено: среди пациентов, проживавших в 1986 г. на радиационно загрязнённых территориях Украины после аварии на Чернобыльской АЭС, не было достоверных различий в развитии устойчивости к радиоактивному йоду (резистентность к ${ }^{131} \mathrm{I}-51,92 \%$ (n = 81); эффрект лечения ${ }^{131} \mid-64,02 \%$ (n = 121)). Эти различия могут быть связаны с более молодым возрастом радиационно пострадавших пациентов и лучшей чувствительностью крадиойоду по сравнению с больными основной группы. Максимальное количество радиойодрезистентных наблюдений было в группе промежуточного риска (71,15%; $n=111)$. Привлекает внимание значительное количество радиойодрезистентных метастазов в группе, где первично они не диагностированы (11,53 \%; n = 18), и в группе, где не выполнена должная оценка состояния лимфатических коллекторов (29,49%; n = 46). В наблюдениях, в которой профилактическая центральная диссекция не проведена, радиойодрезистентность отмечена достоверно чаще (33,97 \%; $\mathrm{n}=53)$.

Выводы. Основные факторы риска развития радиойодрезистентных метастазов - возраст пациентов старше 40 лет, ограниченность первичного оперативного вмешательства на регионарных лимфатических коллекторах шеи, агрессивность опухоли. Тщательность до- и интраоперационной оценки регионарных коллекторов лимфотока, проведение профилактической центральной диссекции шеи и широких терапевтических диссекций позволяют уменьшить риск развития резидуальных и радиойодрезистентных метастазов. Своевременная диагностика метастазов улучшает результаты первичного хирургического лечения пациентов с дифференцированной тиреоидной карциномой и снижает частоту развития радиойодрезистентности.

Metastatic well-differentiated thyroid cancer is treated with radioactive iodine ${ }^{(131}$ I) due to the ability of tumor cells to capture and selectively accumulate the isotope. The positive effect of treatment can be achieved in $60-70 \%$ of patients with small metastatic foci and a high degree of accumulation of the radiopharmaceutical [1].

Some patients develop iodine resistance of metastases, that is, the lack of the ability to capture the isotope, which significantly worsens the prognosis. 5-year disease - free survival rate for iodine resistance is $66 \%$, and 10 -year survival rate does not exceed $10 \%$ [2]. According to the results of various studies, the average life expectancy of patients with iodine-resistant thyroid cancer is from two and a half years to three and a half years from the disease detection [3-5]. It is currently believed that the MAPK signaling pathway activation is the central link in the pathogenesis of papillary thyroid carcinoma. Activation triggers are mutations in the BRAF gene and genes of the RAS family, as well as gene rearrangements with the chimeric RET-PTC gene formation $[6,7]$.
An important role in the development of iodine resistance is played by the transport of iodine to thyrocytes, which occurs against the concentration gradient by activating the sodium iodine symporter. A decrease in the expression of sodium iodine symporter, as well as a decrease in its amount on the membrane of tumor cells, leads to a decrease in functional activity, both of these mechanisms are considered the key factors in the resistance to radioiodine therapy development [6].

The data on the frequency of iodine resistance are contradictory. It has been shown that in $25-66 \%$ of cases, tumor foci either initially do not have a sufficient capacity to accumulate ${ }^{131}$ I or lose it during therapy. It may be due to a decrease in the population of well-differentiated tumor cells and an increase in the number of poorly-differentiated cells incapable of capturing ${ }^{131}$ [8]. In this case, thyroglobulin can not be considered a reliable tumor marker, as decreased cell differentiation and iodine resistance affect the ability of malignant cells to produce thyroglobulin $[9,10]$.
Ключевые слова: карцинома щитовиАной железы, хирургическое мечение, радиойоА резистентные метастазы, радиойодтерапия.

Запорожский медицинский журнал 2021. T. 23, № 5(128) C. $670-676$ 
At all stages of treatment for patients with well-differentiated thyroid cancer, it is always necessary to take into account the risk of developing resistance to radioiodine therapy in order to change the therapeutic program in a timely manner.

The diagnosis of metastases resistant to radioiodine therapy is a controversial issue. It is noted that if metastases of differentiated thyroid cancer progress after an adequate course of radioactive iodine treatment with therapeutic activities of $100 \mathrm{mCi}$ and higher, further ${ }^{131}$ therapy will be ineffective [2,3].

In terms of morphological characteristics and clinical manifestations, iodine-resistant thyroid carcinomas represent a highly heterogeneous group. In some patients, pathological foci may not initially accumulate ${ }^{131}$ I, in others, heterogeneity of the isotope accumulation activity in different foci may be observed; in addition, the resistance to radioactive iodine may develop during treatment. There are examples when pathological foci accumulate ${ }^{131} \mid$ but do not progress, however, a positive therapeutic effect is not observed either, even after repeated courses of radioiodine therapy. In connection with this heterogeneity of the disease, the determination of iodine resistance is an important diagnostic problem, in particular, to define the timing of more effective ${ }^{131}$ I therapy, and, if necessary, to change a treatment tactics. Moreover, long-term use of the radiopharmaceutical is associated with an increased risk of developing secondary tumors and leukemia [2,3].

It should also be noted that, in most cases, iodine-resistant tumors are asymptomatic and patients do not need emergency therapy. Careful and regular follow-up of patients after radical treatment allows, in most cases, early diagnosis of local iodine-resistant metastases in the neck region and their surgical removal without survival rates affection. Though, a case may not always be operable.

Important controversial clinical issues of prevention, early diagnosis, optimization of the combined surgical and systemic treatment strategy for patients with confirmed iodine resistant metastases of well-differentiated papillary thyroid cancer, requiring a study on the treatment results in this group of patients, have remained unresolved to date.

\section{Aim}

This article focuses on the assessment of primary status, characteristics of the tumor process and initial surgical treatment in patients with well-differentiated papillary thyroid carcinomas who subsequently developed resistance to ${ }^{131}$ I therapy comparing with the control group of patients who achieved an adequate response from ${ }^{131}$ I therapy.

\section{Materials and methods}

The work design is a clinical retrospective study. We analyzed 156 cases of well-differentiated papillary thyroid cancer, which showed iodine resistance after a radical treatment, consisting in thyroidectomy, followed by ablative therapy with ${ }^{131}$ I and suppressive hormonal therapy.

The control group consisted of 189 patients who showed complete responses to treatment of metastases after ${ }^{131}$ therapy and a confirmed relapse-free period. The patients were operated and followed up in the Department of Endocrine Gland Surgery of SI "V. P. Komisarenko Institute of Endocrinology and Metabolism of the National Academy of Medical Sciences of Ukraine" between 1990 and 2019.

The study included patients who met the following criteria:

- primary treatment of well-differentiated papillary thyroid carcinoma including total thyroidectomy with or without neck dissection, followed by ${ }^{131}$ I therapy and suppressive hormonal therapy;

- the studied group of iodine-resistant metastases that is the development of one or more metastatic lymph nodes in the neck, mediastinum that do not accumulate ${ }^{131}$ I after the confirmed relapse-free period (diagnostic ${ }^{131}$ | scanning, ultrasound or CT of the neck, thyroglobulin level $<0.20 \mathrm{ng} / \mathrm{ml}$ ), provided that ablative radioiodine therapy is at a therapeutic dose of $3.7 \mathrm{GBq}(100 \mathrm{mCi})$;

- the control comparison group that is the complete response of metastases to ${ }^{131}$ I treatment with the confirmed relapse-free period (diagnostic ${ }^{131}$ I scanning, ultrasound or CT of the neck, thyroglobulin level $<0.20 \mathrm{ng} / \mathrm{ml}$ );

- at least a 6-month patient follow-up period or until death.

At the first stage, the primary characteristics of the disease and initial surgical treatment were comparatively assessed in the control group of patients with the complete response to ${ }^{131} \mathrm{I}$ therapy and in the study group with confirmed iodine resistance.

We evaluated the patient's data (sex, age, living in a radiation-controlled area affected by the Chornobyl accident, clinical manifestations of the disease, risk group); characteristics of the tumor process (stage according to the TNM system, invasiveness, multifocality, morphology); the nature of primary surgical treatment.

Statistical processing of the data was carried out using the Statistica 10.0 Free trial. Calculated using the two tailed Fisher's exact test.

\section{Results}

The data on the prevalence of well-differentiated radioiodine-resistant thyroid cancer in male and female patients are contradictory without a clear relationship according to various studies $[1-3,8]$. Lamartina $L$. and her co-authors (2017) observed the predominance of men in radioiodine-resistant thyroid cancer [10]. In our study, in the group of radioiodine-resistant metastases, there was a 3.1:1.0 predominance of women over men; whereas in the control group, this ratio was 1.4:1.0.

The most significant factor in the development of radioiodine resistance was the age, which was consistent with many studies $[2,3,5]$. The adequate response to radioactive iodine therapy for metastases of well-differentiated thyroid cancer is known, especially in young patients [10]. It was noted that the radioactive iodine resistance in patients under the age of 20 years was 4 times significantly lower (10.26\%) comparing with the group of effective treatment of metastases (41.90\%) (Fig. 1, Table 1). In the age group of 21-40 years, patients with positive dynamics following the radioactive iodine therapy of metastases also dominated $(50.79 \%$ and $39.10 \%$, respectively). In age groups over 40 years, there was a different situation in favor of 
an increase in the number of iodine resistance cases. In the age group of 41-60 years, radioiodine resistance was 6.5 times higher in contrast to the comparison group $(39.10 \%$ and $6.35 \%)$ and at the age of over 61 years, it was 11 times higher ( $11.54 \%$ and $1.05 \%$ ).

The presence of patients in the radiation-affected area after the 1986 Chornobyl Nuclear Power Plant accident (Kyiv, Chernihiv, Zhytomyr, Rivne, Cherkasy, Volyn regions) did not show a great influence on the metastases resistance to radioactive iodine $(51.92 \% ; n=81)$, but it was significant in the control group with responsive metastases $(64.02 \% ; n=121)$ due to the young age of radiation-injured patients who responded to radioactive iodine therapy.

The clinical manifestations of thyroid cancer (palpable tumor, dysphagia, dysphonia) did not differ significantly between the groups being compared; most of the cancer cases were asymptomatic and detected when the patients were treated for another disease.

Risk stratification by groups was carried out at the time of primary treatment. In the low-risk group, the number of radioiodine-resistant metastases was minimal (4.49\%; $\mathrm{n}=7$ ). The maximum number of radioiodine-resistant cases was in the intermediate risk group $(71.15 \% ; n=111)$. There were 38 patients in the high-risk group $(24.36 \%)$ with radioiodine resistance.

The stage of the tumor process at the time of primary treatment influenced the development of radioactive iodine resistance. Microcarcinomas (less than $1 \mathrm{~cm}$ in size) without extrathyroidal extension were less likely to show resistance to radioactive iodine (9.62 \%; $n=15)$ compared with carcinomas of more progressive stages: pT2 - from $2.1 \mathrm{~cm}$ to $4.0 \mathrm{~cm}(19.87 \% ; \mathrm{n}=31) ; \mathrm{pT} 3-4.1 \mathrm{~cm}$ or more $(28.85 \% ; n=45) ;$ pT4 - a tumor of any size with extracapsular invasion (16.02 \%; $n=25)$, which is natural and corresponds to the literature data [5].

The analysis of regional metastasis of carcinomas is of practical interest. The diagnosed metastases of the median and lateral neck responded to radioactive iodine therapy, and the indicators in the control group with response to therapy were significantly better than those in cases of radioiodine resistance (Table 2). Noteworthy is a significant number of radioiodine-resistant metastases in the group where their absence was initially diagnosed (11.53\%; $\mathrm{n}=18$ ) and in the group where the lymphatic collector state was not properly assessed $(29.49 \% ; n=46)$, indicating the importance of pre- and intraoperative diagnosis of regional metastasis in establishing the diagnosis of well-differentiated thyroid carcinoma. Many authors note the importance of the metastasis diagnosis in the preoperative period by an experienced doctor of ultrasound diagnostics and the thoroughness of intraoperative revision of the neck compartments, most often affected by metastases $[9,10]$. In our observations, the most frequent anatomical localization of radioiodine-resistant metastases of papillary thyroid carcinoma to the regional lymph nodes of the neck were level $\mathrm{VI}$ of the central compartment, as well as levels II, III, IV of the lateral triangles of the neck (Fig. 2).

The importance of performing an oncological adequate neck dissection in order to prevent the development of residual and radio-resistant metastases is confirmed by the analysis of surgical interventions on the neck lymphatic
Table1. Radioiodine-resistant metastases of well-differentiated thyroid carcinoma in the age groups, $n(\%)$

\begin{tabular}{|l|l|l|l|}
\hline Age groups, years & $\begin{array}{l}\text { Metastases } \\
\text { showing } \\
\text { radioiodine } \\
\text { resistance }\end{array}$ & $\begin{array}{l}\text { Complete } \\
\text { response } \\
\text { to } 131 \text { therapy } \\
\text { for metastases }\end{array}$ & $\begin{array}{l}\text { According } \\
\text { to two tailed } \\
\text { Fisher's exact } \\
\text { test }\end{array}$ \\
\hline Under 20 & $16(10.26)$ & $79(41.9)$ & $<0.0001$ \\
\hline $21-40$ & $61(39.10)$ & $96(50.79)$ & 0.039 \\
\hline $41-60$ & $61(39.10)$ & $12(6.35)$ & $<0.0001$ \\
\hline 61 and older & $18(11.54)$ & $2(1.05)$ & $<0.0001$ \\
\hline
\end{tabular}

Table 2. Regional metastasis of papillary thyroid carcinoma, $\mathrm{n}(\%)$

\begin{tabular}{l|l|l|l}
\hline Regional metastasis & $\begin{array}{l}\text { Metastases } \\
\text { showing } \\
\text { radioiodine } \\
\text { resistance }\end{array}$ & $\begin{array}{l}\text { Complete } \\
\text { response to } \\
\text { 131] therapy } \\
\text { for metastases }\end{array}$ & $\begin{array}{l}\text { According } \\
\text { to two tailed } \\
\text { Fisher's } \\
\text { exact test }\end{array}$ \\
\hline$N_{0}$ Absence of regional metastasis & $18(11.53)$ & $0(0.0)$ & 0.065 \\
\hline$N_{1 a}$ Median neck metastases & $33(21.15)$ & $68(35.98)$ & 0.018 \\
\hline $\begin{array}{l}N_{1 b} \text { Metastases of the lateral neck, unilateral } \\
\text { or bilateral }\end{array}$ & $59(37.82)$ & $121(64.02)$ & 0.001 \\
$\begin{array}{l}\mathrm{N}_{\mathrm{x}} \text { Regional lymph nodes which can not be } \\
\text { assessed }\end{array}$ & $46(29.49)$ & $0(0.0)$ & 0.001 \\
\hline
\end{tabular}

Table 3. The neck dissection in regional metastasis of papillary thyroid carcinoma, $\mathrm{n}(\%)$

\begin{tabular}{l|l|l|l} 
Neck dissection & $\begin{array}{l}\text { Metastases } \\
\text { showing } \\
\text { radioiodine } \\
\text { resistance }\end{array}$ & $\begin{array}{l}\text { Complete } \\
\text { response } \\
\text { to }{ }^{131} \text { therapy } \\
\text { for metastases }\end{array}$ & $\begin{array}{l}\text { According } \\
\text { to two tailed } \\
\text { Fisher's } \\
\text { exact test }\end{array}$ \\
\hline Preventive neck dissection & $36(23.08)$ & $49(25.93)$ & \\
\hline Therapeutic neck dissection & $65(41.66)$ & $124(65.61)$ & $<0.0001$ \\
\hline Unilateral central dissection & $9(5.78)$ & $9(4.76)$ & \\
\hline Bilateral central dissection & $80(51.28)$ & $149(78.83)$ & $<0.0001$ \\
\hline Central dissection was not performed & $53(33.97)$ & $10(5.29)$ & $<0.0001$ \\
\hline
\end{tabular}

Table 4. Regional metastasis morphology of papillary thyroid carcinoma, $\mathrm{n}(\%)$

\begin{tabular}{|c|c|c|c|}
\hline Morphology & $\begin{array}{l}\text { Metastases } \\
\text { showing } \\
\text { radioiodine } \\
\text { resistance }\end{array}$ & $\begin{array}{l}\text { Complete } \\
\text { response } \\
\text { to }{ }^{131} \mid \text { therapy } \\
\text { for metastases }\end{array}$ & $\begin{array}{l}\text { According } \\
\text { to two tailed } \\
\text { Fisher's } \\
\text { exact test }\end{array}$ \\
\hline Typical papillary thyroid carcinoma & $65(41.68)$ & $40(21.16)$ & 0.0001 \\
\hline Oxyphilic cell papillary thyroid carcinoma & $20(12.82)$ & $12(6.35)$ & 0.0305 \\
\hline $\begin{array}{l}\text { Sclerosing variant of papillary thyroid } \\
\text { carcinoma }\end{array}$ & $13(8.34)$ & $19(10.05)$ & \\
\hline $\begin{array}{l}\text { Solid follicular variant of papillary thyroid } \\
\text { carcinoma }\end{array}$ & $7(4.49)$ & $56(29.64)$ & $<0.0001$ \\
\hline $\begin{array}{l}\text { Follicular variant of papillary thyroid } \\
\text { carcinoma }\end{array}$ & $41(26.28)$ & $62(32.80)$ & \\
\hline Follicular thyroid carcinoma & $9(5.78)$ & $0(0.0)$ & 0.0007 \\
\hline Poorly differentiated tumor & $1(0.61)$ & $0(0.0)$ & \\
\hline
\end{tabular}

collectors in the primary treatment of thyroid carcinoma (Fig. 3, Table 3). Radical dissections of a preventive and therapeutic nature showed a significant decrease in the number of observations of iodine-resistant metastases (Fig. 4). It is especially important to note the need to perform preventive central neck dissection [10]. In the observations where prophylactic central dissection was not performed, radioiodine resistance was found significantly more often (33.97\%; $n=53)$.

The aggressiveness of cancer morphology is one of the factors determining the radioiodine resistance of a tumor 

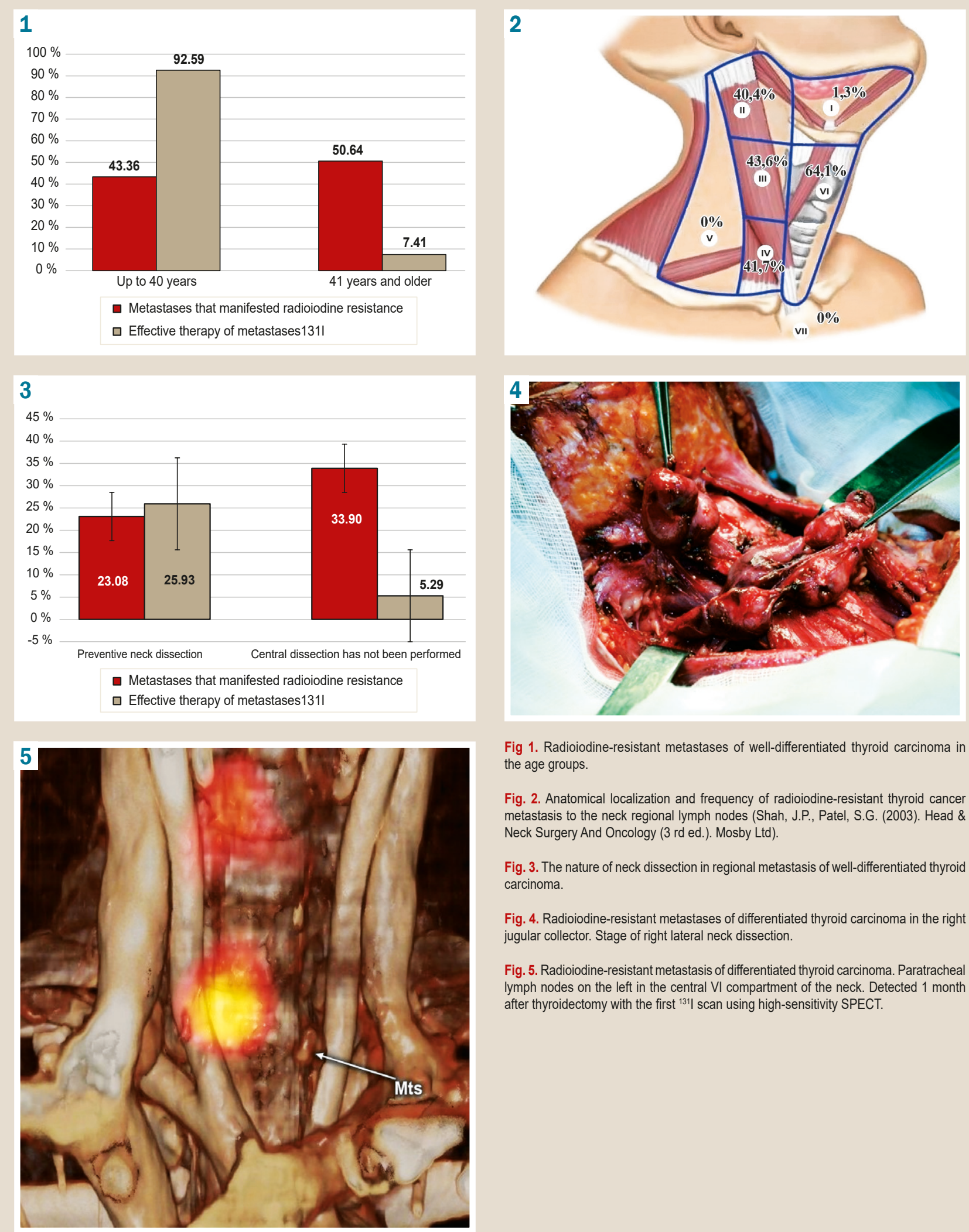

Fig 1. Radioiodine-resistant metastases of well-differentiated thyroid carcinoma in the age groups.

Fig. 2. Anatomical localization and frequency of radioiodine-resistant thyroid cancer metastasis to the neck regional lymph nodes (Shah, J.P., Patel, S.G. (2003). Head \& Neck Surgery And Oncology (3 rd ed.). Mosby Ltd).

Fig. 3. The nature of neck dissection in regional metastasis of well-differentiated thyroid carcinoma.

Fig. 4. Radioiodine-resistant metastases of differentiated thyroid carcinoma in the right jugular collector. Stage of right lateral neck dissection.

Fig. 5. Radioiodine-resistant metastasis of differentiated thyroid carcinoma. Paratracheal lymph nodes on the left in the central VI compartment of the neck. Detected 1 month after thyroidectomy with the first ${ }^{131}$ I scan using high-sensitivity SPECT.

[4]. In our study, radioiodine resistance was more often in a typical variant of papillary thyroid carcinoma $(41.68 \%$, $\mathrm{n}=65)$; follicular variant of papillary carcinoma (26.28\%, $\mathrm{n}=41$ ); oxyphilic cell variant of papillary carcinoma $(12.82 \%, n=20)$ (Table 4).
Undoubtedly, taking into account the risk factors characterizing the primary characteristics of the tumor process at the beginning of the treatment, the performed surgical intervention nature is essential for predicting the development of possible radioiodine resistance in well-differentiated thyroid carcinomas. 


\section{Discussion}

Resistance to radioactive iodine of well-differentiated thyroid cancer metastases has become a significant problem in recent years, affecting treatment outcomes. Therefore, the most important task is to identify the specific moment in time when the radioactive iodine therapy can not be used effectively, and it is necessary to change therapy tactics.

Clinical analysis of well-differentiated thyroid carcinomas resistant to ${ }^{131}$ I treatment allowed us to determine the most significant criteria for establishing diagnosis in accordance with the international recommendations $[2,3]$.

The discussion of iodine-resistant metastases can take place during the very first course of ${ }^{131}$ I therapy, when residual metastases are detected a month after radical surgical treatment $[1,4]$. The presence of at least 1 lesion visualized on ultrasound, CT/MRI, that does not accumulate radioactive iodine, provided that if radioiodine therapy $(100 \mathrm{mCi})$ and post-treatment whole-body scintigraphy is performed adequately, can serve as a criterion for radioactive resistance.

Analysis of radioactive iodine-resistant cancer forms showed that in the high-risk group, early detection of iodine-resistant metastases is possible with the first ${ }^{131}$ | scan using high-sensitivity single-photon emission computed tomography (SPECT) after the adequate oncological primary surgery (Fig. 5). Exact comparison of anatomical and functional images allows differentiation of isotope accumulation foci and metastases that do not capture radioactive iodine $[1,8]$.

The absence of radioactive iodine absorption in some, but not all, lesions, that is, a mixed picture with foci accumulating and not accumulating isotope, can be considered refractory. With a mixed nature of absorption, continuation of therapy with radioactive iodine in combination with the removal of iodine-resistant metastases can be discussed.

Our observations, as well as studies of other authors, have shown that patients can be defined as resistant to radioactive iodine in a more distant period, when there is a progressive loss of the isotope uptake after several sessions of radioiodine therapy $[2,3,5]$. Often, radioiodine refractory status is determined by an 18FDG-PET study following the detection of increased thyroglobulin and negative radioactive iodine body scans.

In this case, the indicator of the biochemical progression of thyroglobulin is important. Tumor load can be assessed by dynamic thyroglobulin levels; rapid progression and poor prognosis can be predicted by thyroglobulin doubling time in less than 1 year.

Most authors consider that the main clinical task is the early detection of iodine-resistant metastases and their surgical removal $[1-3,5,8]$. Local recurrences in the neck and mediastinum are the most common sites of metastasis, followed by the lungs, extracervical lymph nodes, bones, and the brain.

For locoregional recurrence, surgery is the most commonly used approach. Indications for local therapy in radioiodine-refractory differentiated thyroid cancer are based on the location and number of metastases, tumor size and technical capability. In case of locoregional recurrence, surgery is the best option, even in cases of radio- active iodine trapping. The volume of surgical intervention is determined individually, it can be radical, palliative in order to remove aerodigestive obstruction, and it can be combined with external radiation therapy. The type of cervical dissection varies depending on the lesion nature and it should be radical. The most common dissection is the central compartment of the neck, lateral dissection in the area of the anterior and posterior triangles of the neck. With previously performed extensive operations, limited selective dissection in the affected area is justified $[9,10]$.

Reoperation for radioiodine-resistant regional metastases, according to many authors, requires careful preparation to assess the balance between the risk and benefit of surgical intervention $[9,10]$. It is necessary to conduct a clear anatomical and topographic localization of the lesion (ultrasound of the neck with a high-resolution, computed tomography of the neck, chest, abdomen and brain according to the oncological screening program, SPECT) with mandatory cytological confirmation of malignancy.

Recently, a large number of studies have been published on the need for prophylactic dissection of lymph nodes in the central compartment of the neck as a method of surgical prophylaxis of radioiodine resistance, which allows detecting micrometastasis morphologically in almost $60 \%$ of cases [9]. There is no doubt that prophylactic central dissection increases the radicality of the intervention and achieves zero levels of postoperative stimulated thyroglobulin, thereby reducing ablative doses of radioactive iodine in low-risk patients.

The decision-making should always be discussed with a patient. In cases of high risk and impossibility of radical tumor removal, many surgeons recommend a more conservative approach, alternative methods of local impact on the tumor, discussion of targeted therapy with multikinase inhibitors [1-4].

We agree with the most oncologists that for radioiodine-resistant cancer, treatment with multikinase inhibitors should only be considered in patients with advanced disease, significant tumor burden, and when a refusal from the treatment with multikinase inhibitors may lead to significant harm or clinical complications in the near future in the opinion of an interdisciplinary group of experts $[2,3]$. Modern thyroid oncosurgery should anticipate the possibility of radioiodine-resistant metastases at the beginning of treatment, assessing the tumor process, and the therapy nature, stratifying risk groups. Undoubtedly, the earlier detection of radioactive iodine-resistant metastases of well-differentiated thyroid cancer will allow their radical surgical removal in a timely manner.

\section{Conclusions}

1. The possibility of developing radioiodine resistance of well-differentiated thyroid cancer should be considered when planning the nature of primary treatment, taking into account risk factors.

2. The main risk factors for the development of radioiodine-resistant metastases were the age of patients older than 40 years and the radicality of primary surgery on regional lymphatic collectors of the neck.

3. Careful pre- and intraoperative assessment of regional collectors of the lymph outflow, preventive central neck 
dissection and extensive therapeutic dissections can reduce the risk of residual and radioiodine-resistant metastases.

4. The frequent anatomical localization of radioiodine-resistant metastases of papillary thyroid carcinoma in the regional lymph nodes of the neck were - VI level of the central compartment, as well as II, III, IV levels of the lateral triangles of the neck. Special attention should be paid to these anatomical areas during surgery and patient examination. Timely diagnosis of metastases can improve the results of primary surgical treatment for patients with differentiated thyroid carcinoma and reduce the incidence of radioiodine-resistant metastases.

Prospects for further research are both to expand the sample of patients and to determine the reasons for the development of radioiodine resistance of well-differentiated thyroid cancer to ${ }^{131} \mathrm{I}$ accumulation. Prevention of the radioactive iodine resistance development during treatment. To improve preoperative diagnosis of thyroid cancer, individualize the therapeutic tactics; stratification and management of patients in the long-term postoperative period.

\section{Funding}

The work is a fragment of the research of SI "V. P. Komisarenko Institute of Endocrinology and Metabolism of the National Academy of Medical Sciences of Ukraine": "Optimization of diagnosis, surgical treatment and prediction of thyroid tumors, adrenal gland incidence and parathyroid adenomas", state registration No. 0120 U100647.

Conflicts of interest: authors have no conflict of interest to declare. Конфлікт інтересів: віАсутній.

Надійшла Ао редакції / Received: 25.02.2021

Після Аоопрацювання / Revised: 11.03.2021

Прийнято Ао Аруку / Accepted: 23.04.2021

Information about authors:

Ostafiichuk M. V., Researcher, Department of Endocrine Gland Surgery, SI “V. P. Komisarenko Institute of Endocrinology and Metabolism of the National Academy of Medical Sciences of Ukraine", Kyiv.

ORCID ID: 0000-0002-0446-051X

Kovalenko A. Ye., MD, PhD, DSc, Professor, Head of

the Department of Endocrine Gland Surgery,

SI "V. P. Komisarenko Institute of Endocrinology and Metabolism of the National Academy of Medical Sciences of Ukraine", Kyiv. ORCID ID: 0000-0003-0326-6421

Tarashchenko Yu. M., MD, PhD, Senior Researcher, Department of Endocrine Gland Surgery, SI “V. P. Komisarenko Institute of Endocrinology and Metabolism of the National Academy of Medical Sciences of Ukraine", Kyiv.

ORCID ID: 0000-0003-4787-359X

\section{Відомості про авторів:}

Остафійчук М. В., науковий співробітник віАділу хірургії енАокринних залоз, АУ “Інститут енАокринології та обміну речовин імені В. П. Комісаренка НАМН України", м. Київ. Коваленко А. Є., А-р меА. наук, професор, керівник відаілу хірургії енАокринних залоз, АУ «Інститут енАокринології та обміну речовин імені В. П. Комісаренка НАМН України», м. Київ.

Таращенко Ю. М., канА. меА. наук, старший науковий співробітник віААілу хірургії ендокринних залоз, АУ «Інститут ендокринології та обміну речовин імені В. П. Комісаренка НАМН України", м. Київ.
Сведения об авторах:

Остафийчук М. В., научный сотрудник отАела хирургии энАокринных желез, ГУ “Институт энАокринологии и обмена веществ имени В. П. Комиссаренко НАМН Украины", г. Киев. Коваленко А. Е., А-р меА. наук, профессор, руководитель отАела хирургии энАокринных желез, ГУ “Институт энАокринологии и обмена веществ имени В. П. Комиссаренко НАМН Украины", г. Киев.

Таращенко Ю. Н., канА. меА. наук, старший научный сотрудник отАела хирургии эндокринных желез, ГУ "Институт эндокринологии и обмена веществ имени В. П. Комиссаренко НАМН Украины", г. Киев.

\section{References}

[1] Van Nostrand D. (2018). Radioiodine Refractory Differentiated Thyroid Cancer: Time to Update the Classifications. Thyroid, 28(9), 1083-1093. https://doi.org/10.1089/thy.2018.0048

[2] Capdevila, J., Galofré, J. C., Grande, E., Zafón Llopis, C., Ramón Y Cajal Asensio, T., Navarro González, E., Jiménez-Fonseca, P., Santamaría Sandi, J., Gómez Sáez, J. M., \& Riesco Eizaguirre, G. (2017). Consensus on the management of advanced radioactive iodine-refractory differentiated thyroid cancer on behalf of the Spanish Society of Endocrinology Thyroid Cancer Working Group (GTSEEN) and Spanish Rare Cancer Working Group (GETHI). Clinical and Translational Oncology, 19(3), 279-287. https://doi.org/10.1007/s12094-016-1554-5

[3] Fugazzola, L., Elisei, R., Fuhrer, D., Jarzab, B., Leboulleux, S., Newbold, K., \& Smit, J. (2019). 2019 European Thyroid Association Guidelines for the Treatment and Follow-Up of Advanced Radioiodine-Refractory Thyroid Cancer. European Thyroid Journal, 8(5), 227-245. https://doi.org/10.1159/000502229

[4] Anderson, R. T., Linnehan, J. E., Tongbram, V., Keating, K., \& Wirth, L. J. (2013). Clinical, Safety, and Economic Evidence in Radioactive lodine-Refractory Differentiated Thyroid Cancer: A Systematic Literature Review. Thyroid, 23(4), 392-407. https://doi.org/10.1089/ thy. 2012.0520

[5] Gild, M. L., Topliss, D. J., Learoyd, D., Parnis, F., Tie, J., Hughes, B. Walsh, J. P., McLeod, D., Clifton-Bligh, R. J., \& Robinson, B. G. (2018). Clinical guidance for radioiodine refractory differentiated thyroid cancer. Clinical Endocrinology, 88(4), 529-537. https://doi. org/10.1111/cen. 13508

[6] Aashiq, M., Silverman, D. A., Na'ara, S., Takahashi, H., \&Amit, M. (2019). Radioiodine-Refractory Thyroid Cancer: Molecular Basis of Redifferentiation Therapies, Management, and Novel Therapies. Cancers, 11(9) Article 1382. https://doi.org/10.3390/cancers11091382

[7] Tarashchenko, Yu. M., Kovalenko, A. Ye., Ostafiichuk, M. V., \& Nekrasov, K. A. (2020). BRAF-status u tsytomorfolohichnii diahnostytsi tyreoidnykh vuzliv [BRAF status in cito-morphological diagnosis of thyroid nodules]. Pathologia, 17(2), 178-183. https://doi.org/10.14739/2310 1237.2020.2.212783 [in Ukrainian]

[8] Narayanan, S., \& Colevas, A. D. (2016). Current Standards in Treatment of Radioiodine Refractory Thyroid Cancer. Current Treatment Options in Oncology, 17(6), Article 30. https://doi.org/10.1007/s11864-016-0404-6

[9] Lee, H. S., Roh, J. L., Gong, G., Cho, K. J., Choi, S. H., Nam, S. Y., \& Kim, S. Y. (2015). Risk Factors for Re-recurrence After First Reoperative Surgery for Locoregional Recurrent/Persistent Papillary Thyroid Carcinoma. World Journal of Surgery, 39(8), 1943-1950. https://doi org/10.1007/s00268-015-3052-2

[10] Lamartina, L., Borget, I., Mirghani, H., Al Ghuzlan, A., Berdelou, A. Bidault, F., Deandreis, D., Baudin, E., Travagli, J. P., Schlumberger, M., Hartl, D. M., \& Leboulleux, S. (2017). Surgery for Neck Recurrence of Differentiated Thyroid Cancer: Outcomes and Risk Factors. The Journal of Clinical Endocrinology \& Metabolism, 102(3), 1020-1031. https://doi. org/10.1210/jc.2016-3284 